\title{
International cooperation of hospital ship SS HOPE in Natal (1972): health care and education
}

\author{
Cooperação internacional do navio-hospital SS HOPE em Natal (1972): assistência e educação em saúde \\ Cooperación internacional del buque hospital SS HOPE en Natal (1972): salud y educación
}

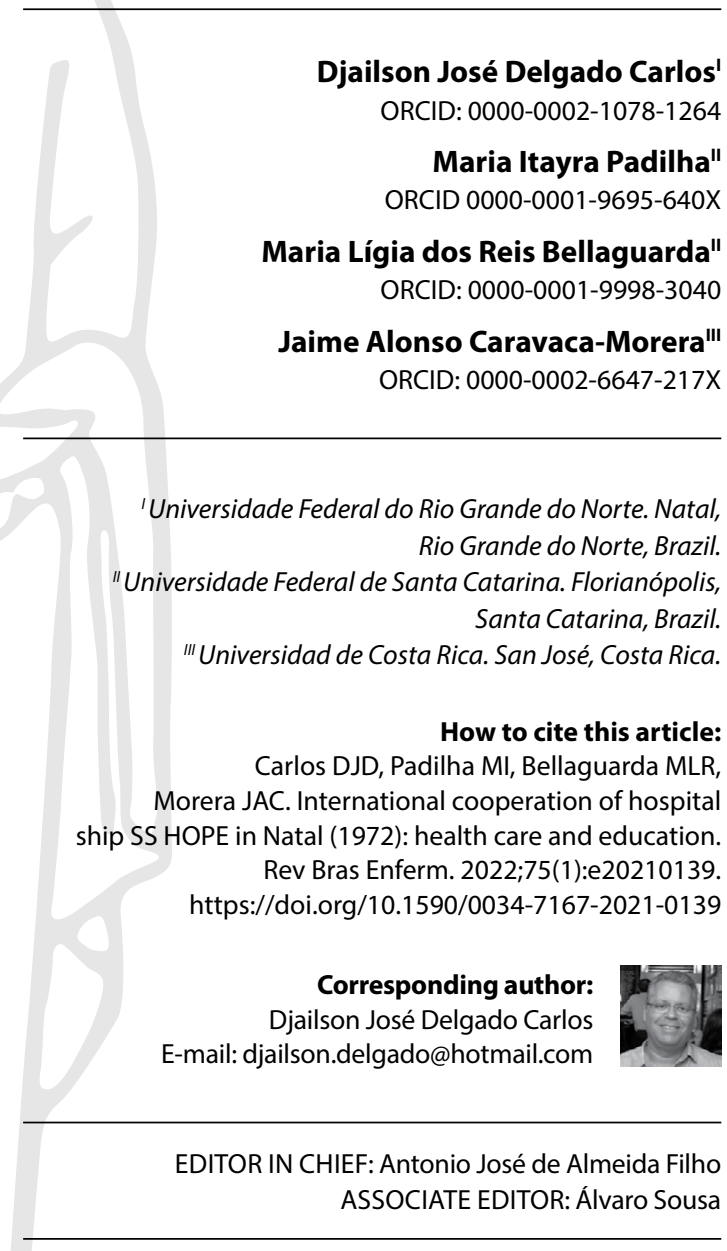

Submission: $03-11-2021$

Approval: 04-26-2021

\begin{abstract}
Objective: to analyze the activities developed by hospital ship SS HOPE in Natal. Method: this is a qualitative, socio-historical study, elaborated from documentary sources and 16 interviews with health professionals. Thematic Oral History was used for data treatment and analysis. Results: the empirical material identified a wide schedule of courses and lectures as well as made it possible to elaborate the following categories: Health education on hospital ship SS HOPE; Legacy of international cooperation of hospital ship SS HOPE; Statements about the season of hospital ship SS HOPE. Final considerations: the arrival and stay of this hospital ship, for ten months, is the result of negotiations between the University, the State Government and the People to People Foundation. During their stay, education and health care actions were carried out, with the joint participation of health professionals, Potiguares and Americans. Descriptors: International Cooperation; Delivery of Health Care; Health Education; Health Workforce; Relief Work.
\end{abstract}

\section{RESUMO}

Objetivo: analisar as atividades desenvolvidas pelo navio-hospital SS HOPE em Natal. Método: estudo qualitativo, sócio-histórico, elaborado a partir de fontes documentais e da realização de 16 entrevistas com profissionais de saúde. Utilizou-se a História Oral Temática para o tratamento e a análise dos dados. Resultados: o material empírico identificou uma vasta programação de cursos e palestras, assim como possibilitou a elaboração das seguintes categorias: Educação em saúde no navio-hospital SS HOPE; Legado da cooperação internacional do navio-hospital SS HOPE; Enunciados sobre a temporada do navio-hospital SS HOPE. Considerações finais: a vinda e permanência desse navio-hospital, por dez meses, é fruto da negociação entre a Universidade, o Governo do estado e a People to People Foundation. Durante sua estadia, foram realizadas ações de educação e assistência à saúde, com a participação conjunta de profissionais de saúde, potiguares e estadunidenses. Descritores: Cooperação Internacional; Assistência à Saúde; Educação em Saúde; Recursos Humanos para a Saúde; Ajuda Humanitária.

\section{RESUMEN}

Objetivo: analizar las actividades desarrolladas por el buque hospital SS HOPE en Natal. Método: estudio cualitativo, sociohistórico, basado en fuentes documentales y 16 entrevistas a profesionales de la salud. Se utilizó la Historia Oral Temática para el tratamiento y análisis de los datos. Resultados: el material empírico identificó un amplio programa de cursos y conferencias, además de posibilitar el desarrollo de las siguientes categorías: Educación para la salud en el buque hospital SS HOPE; Legado de la cooperación internacional del buque hospital SS HOPE; Declaraciones sobre la temporada del buque hospital SS HOPE. Consideraciones finales: la llegada y permanencia de este buque hospital, por diez meses, es el resultado de negociaciones entre la Universidad, el Gobierno del Estado y el People to People Foundation. Durante su estadía se realizaron acciones de educación y salud, con la participación conjunta de profesionales de la salud, potiguares y estadounidenses.

Descriptores: Cooperación Internacional; Asistencia a Salud; Educación en Salud; Recursos Humanos para la Salud; Ayuda Humanitaria. 


\section{INTRODUCTION}

Hospital ship SS HOPE (Health Opportunity for People Everywhere), popularly known as The Hope Ship, operated as a transfer of the U.S. government to the People to People Foundation ${ }^{(1)}$, carrying out cruises (1960-1973), in the context of Cold War as a consequence of World War II, in which the super powers - the United States and soviet Union - vied for global hegemony. Its mission was to international cooperation with developing countries, bringing humanitarian aid and developing actions focused on education and health care.

It corresponds to an initiative of American foreign policy, in which the government paid the expenses for the ship maintenance; the cardiologist William B. Walsh, as founder (1958) and president of the Foundation, was responsible for raising financial resources, inputs and the composition of a volunteer team of health professionals (doctors, nurses, dentists, technicians, etc.) (2). This team was responsible for developing health care and education actions through joint work between counterparts in the system known as counterparts ${ }^{(1)}$.

In this condition, the ship's story records the following trips: Indonesia and South Vietnam (1960), Peru (1962-63), Ecuador (1963-64), Guinea (1964-65), Nicaragua (1966), Colombia (1967), Ceylon (1968-69), Tunisia (1969-70), West Indies (1971), all lasting 10 months and, in an unprecedented way, in Brazil where the ship was on two occasions, in Natal (1972) and Maceió (1973). This fact, apparently unusual, may relate to the following circumstances: geopolitical interests; Cold War; political instability in Latin America; precarious health services; lack of human resources in health; previous experiences of humanitarian aid programs in the North and the Northeast; and, use of military bases during World War II(3-4).

Thus, its coming and stay in Natal, capital of the state of Rio Grande do Norte (RN), located in northeastern Brazil, in 1972, for ten months (February to December), resulted, first, from the agreement signed between Universidade Federal do Rio Grande do Norte (UFRN) and the State Government, in the people of Genário Alves da Fonseca and José Cortez Pereira de Araújo, rector and governor, respectively ${ }^{(5)}$. Signed on October 5, 1971, it mobilized the State Departments of Planning and Health, represented, in this order, by Marcos Formiga Ramos and Genibaldo Barros, ensuring financial resources in the amount of $\mathrm{Cr} \$ 40,000.00$ (forty thousand cruises, corresponding to 177 current minimum wages), and the parties (UFRN and State) were responsible for subsidy in equal amounts. Moreover, the University was responsible for receiving, executing and moving resources and, for the State Government, acting as a fiscal body. After that, negotiations were established with People to People Foundation.

It is possible to conjecture that the materialization of this international cooperation was taking on contours as measures ${ }^{(6)}$ and negotiations ${ }^{(7)}$ evolved. Thus, this expressive study is due to the record gap on this important episode in the history of health, in RN and at the University. To this end, the time frame of 1972 - February $16^{(1)}$ to December $6^{(8)}$ - corresponds to the period in which hospital ship SS HOPE was docked in Natal and developing its activities, the object of this study.

\section{OBJECTIVE}

To analyze the activities developed by hospital ship SS HOPE in Natal.

\section{METHODS}

\section{Ethical aspects}

The study complied with the recommendations of Resolutions $466 / 12^{(9)}$ and $510 / 16^{(10)}$ of the Brazilian National Health Council (Conselho Nacional de Saúde) of the Ministry of Health, which regulate research involving human beings. It had the approval of the research project by the Institutional Review Board of Universidade Federal de Santa Catarina.

\section{Type of study}

This is a qualitative, descriptive study of a socio-historical approach, based on the precepts of Oral History ${ }^{(11)}$, with special attention to understanding the social context and its determinants through the rescue of memories and narratives of characters. Such resources when marked with documentary sources ensure reliability to the reconstruction of historical events. It should be reported that the material was assessed in line with the Consolidated Criteria for Reporting Qualitative Research (COREQ) ${ }^{(12)}$, in order to ensure greater credibility to the data and to achieve the important aspects of the research and its interpretations.

\section{Study setting}

Research developed in Natal, capital of RN, referring to the passage of hospital ship SS HOPE, in 1972, the peak of the military regime established since 1964. At that time, the state faced difficulties regarding health care and UFRN presented itself as the only institution that trained higher education professionals, yet with limited supply of courses in the health area. This international cooperation included professionals from university hospitals and public health institutions, in the capital and in the countryside of the state.

\section{Data collection and organization}

Data collection occurred in two moments: first, with the survey of documentary sources in the State General Archive, Historical and Geographic Institute of Rio Grande do Norte, in the Central Library Zila Mamede/UFRN and in the journal Tribuna do Norte and, later, when identifying oral sources.

Employees with proven experience in hospital ship SS HOPE's activities voluntarily participated. Therefore, 16 interviews were conducted with: three State Departments (Education, Health, and Planning); five teaching nurses of a Nursing Course/UFRN; two medical professors of a Medical Course/UFRN; two nursing technicians at Hospital Universitário Onofre Lopes (HUOL/UFRN); a nurse from HUOL/UFRN; three former students of a School of Nurses, Mossoró/RN. All of them occurred through the presentation, reading and signing of the Informed Consent Form (ICF), 
individualized, recorded, transcribed; later, the interviews were validated $^{(11)}$ by participants. If they agreed, the Interview Assignment Term was signed and the interviewees' identification was allowed by their surnames followed by their profession as a possibility to understand the different perspectives.

\section{Data analysis}

Thematic Oral History ${ }^{(13)}$ was used for talking about specific themes and for seeking an understanding of the events present in the narratives and their discussions with documentary sources. For its scope, pre-analysis, material exploration and treatment of results obtained and interpretation ${ }^{(14)}$ were fulfilled. At the end of this process, the following categories emerged: Health education on hospital ship SS HOPE; Legacy of international cooperation of hospital ship SS HOPE; Statements about the season of hospital ship SS HOPE.

\section{RESULTS}

For this research, the survey of documentary sources provided the finding that the arrival and permanence of hospital ship SS
HOPE, in Natal, in 1972, resulted in a voluminous journalistic production and that educational events - courses and lectures - received special attention from the local press.

With regard to the courses, the sources made it possible to locate the realization of nine courses, in the period between March and November 1972. For visualization and better understanding of the data, schedule will be presented in Chart 1.

This organization contributed to quantification of courses and allowed the visualization of schedule, the participants and those responsible for dissemination. Attention is drawn to theme heterogeneity and diversification of the public - professionals and students of local health and surrounding states. Some courses seem to serve the interests of UFRN, given the publication of resolutions of the Teaching, Research and Extension Council (CONSEP - Conselho de Ensino, Pesquisa e Extensão). Nevertheless, the documentary sources were inaccurate regarding the duration, workload and issuance of certificates.

About the lectures, given their similarities to the dialogued lectures and because they consist of teaching-learning processes with less didactic-pedagogical device, perhaps the most intense schedule is justified. In number of 19 , they were carried out between May and November 1972, as shown in Chart 2.

Chart 1 - Schedule of courses held in partnership with hospital ship SS HOPE, Natal, Rio Grande do Norte, Brazil, 2020

\begin{tabular}{|l|l|l|}
\hline \multicolumn{1}{|c|}{ Schedule } & \multicolumn{1}{|c|}{ Public } & Journal \\
\hline 1. Extension Course in Neonatology & Doctors from Pernambuco, Alagoas, Ceará and Paraíba. & $\begin{array}{l}\text { UFRN, CONSEPE Resolution 17 of } \\
03.27 .1972\end{array}$ \\
\hline 2. Hospital Pharmacy & $\begin{array}{l}\text { Professors and students of pharmacy school of Universidade } \\
\text { Federal da Paraíba and UFRN. }\end{array}$ & A República, 06.04.1972; p.03 \\
\hline 3. Pediatric Dentistry and Dental Prosthesis & School of Dentistry/UFRN. & Tribuna do Norte, 14.04.1972; p. 08 \\
\hline 4. Anesthesia Course & $\begin{array}{l}\text { Doctors and doctoral students of medicine/UFRN, Recife and } \\
\text { João Pessoa. }\end{array}$ & Tribuna do Norte, 09.06.1072; p. 08 \\
\hline 5. Extension Course in Pediatric Surgery & Doctors and medical students/UFRN. & $\begin{array}{l}\text { UFRN, CONSEPE Resolution 24 of } \\
06.12 .1972\end{array}$ \\
\hline $\begin{array}{l}\text { 6. Extension Course in Current State of Burn } \\
\text { Treatment }\end{array}$ & Professors and medical students and nursing professionals. & ARepública, 25.06.1972; p, 01 \\
\hline 7. Physiotherapy Course & PhD student of medicine/UFRN. & Tribuna do Norte, 05.07.1972; p. 08 \\
\hline 8. I Hematology Meeting & $\begin{array}{l}\text { Physicians and undergraduate medical students from UFRN, } \\
\text { Bahia, Alagoas, Ceará, Pernambuco and Paraíba. }\end{array}$ & Diário de Natal, 07.10,1972; p. 05 \\
\hline 9. Extension Course in Gynecology Update & Doctors and medical students/UFRN. & $\begin{array}{l}\text { UFRN, CONSEPE Resolution 55 of } \\
11.01 .1972\end{array}$ \\
\hline
\end{tabular}

Chart 2 - Schedule of lectures given in partnership with hospital ship SS HOPE, Natal, Rio Grande do Norte, Brazil, 2020

\begin{tabular}{|l|l|}
\hline Schedule & Journal \\
\hline 1. Dental crown preparation & A República, 05.12.1972; p. 04. \\
\hline 2. Unilateral exophthalmos & A República, 05.12.1972; p.04. \\
\hline 3. Common infectious diseases in Natal & Tribuna do Norte, 06.17.1972; p. 08. \\
\hline 4. Review of interesting radiographs obtained in the current period & Tribuna do Norte, 06.27.1972; p. 01. \\
\hline 5. Eyelid cancer & A República, 07.05.1972; p. 08. \\
\hline 6. Aplastic anemia & Tribuna do Norte, 07.12.1972; p. 08. \\
\hline
\end{tabular}


Chart 2 (concluded)

\begin{tabular}{|l|l|}
\hline Schedule & Journal \\
\hline 7. Juvenile diabetes & A República, 07.19.1972; p. 08. \\
\hline 8. Postoperative morbidity after hysterectomy & Tribuna do Norte, 07.26.1972; p. 08. \\
\hline 9. Use of hypnosis in medicine & Tribuna do Norte, 08.23.1972; p. 08. \\
\hline 10. Surgical treatment of lymphoedema of lower extremities & A República, 08.02.1972; p. 08. \\
\hline 11. Bone graft techniques in oral surgery & A República, 08.30.1972; p. 08. \\
\hline 12. Artificial insertion of the hip joint & Tribuna do Norte, 09.06.1972; p. 08. \\
\hline 13. Obstructive uropathy, infection and multifactorial anemia & A República, 09.13.1972; p. 07. \\
\hline 14. Empyema: an emergency & Diário de Natal, 10.04.1972; p.08. \\
\hline 15. Acute kidney disease & Tribuna do Norte, 10.12.1972; p. 08. \\
\hline 16. Pneumonitis with complications & Diário de Natal, 10.31.1972; p. 08. \\
\hline 17. Mastoiditis with complications & Diário de Natal, 11.14.1972; p.08. \\
\hline 18. Two interesting cases of medical-surgical clinic & Tribuna do Norte, 11.21.1972; p. 08. \\
\hline 19. Two interesting cases of achalasia & A República, 11.28.1972; p. 01. \\
\hline
\end{tabular}

All this material provided in Charts 1 and 2, when correlated to oral sources, enabled the systematization of the following categories: Health education on hospital ship SS HOPE; Legacy of international cooperation of hospital ship SS HOPE; Statements about the season of hospital ship SS HOPE, presented below.

\section{Health education on hospital ship SS HOPE}

In addition to courses and lectures, the exchange of knowledge and experiences was ensured by the work system called counterparts, in which American professionals worked with their Brazilian counterparts. Some interviewees informed about this:

We fulfilled the internship scale inside the ship and assisted classes, often [...] in fact, we received classes all the time [...] there was always a nurse, beside us, teaching and guiding. (Carvalho, student at the School of Nurses of Mossoró)

On the hospital ship, there was a Brazilian nurse who worked with health education for years, in the United States [...] she was my counterpart for 2-3 weeks [...] / followed her during training and recommendations to those who were going to start the internship [...] was the rule, everyone received guidance, first, and then to act. (Coelho, nurse teacher)

We assisted, almost daily, lectures and good conferences, sometimes with doctors, Americans and Potiguares [a Brazilian indigenous group], simultaneously, approaching the same theme under different aspects [...] nursing knowledge was aggregated, both from the point of view of techniques, as from the point of view of pathologies. (Germano, nurse teacher)

Health education was, therefore, a systematic and continuous action, also taking place in the internment unit itself, in this case, on the hospital ship's premises. The narratives confer deliberate actions to the qualification of human resources in health. From this opportunity to know a more advanced center, so to speak, came contacts with innovations, following reported:
Disposables were a great innovation [...] they showed calculations of expenses with the reprocessing of materials, energy, risks of accidents and contamination [...] this awareness, even at that time [...] despite the favorable points, our reality and working conditions were other. (Moura, student at the School of Nurses of Mossoró)

They routinely performed tests to prove the completion of autoclaves and greenhouses cycles and, periodically, performed biological tests [...] as an instructor, I participated in the first corneal transplant done in the state [...] I remember the disposable clothes of the surgical center and the surgical fields attached to the skin. (Araújo Silva, nursing technician)

At that time, Americans already used Jelco for venipunctions, Poliflix for infusion of solutions and catheter for subclavian veins [...] disposable gloves were plentiful and of good quality [...] almost all material was disposable. (Costa, nursing technician)

The first cataract surgeries and corneal transplants in Rio Grande do Norte were performed [...] in situations of new surgical techniques, first they demonstrated and then we also performed the [...] unprecedented use of the surgical stapler [...] the disposable materials were a marvel. (Silva Júnior, medical teacher)

In view of this, this international cooperation allowed access to innovations, with special emphasis, at the time, to disposable supplies - gloves, Jelcos (brand), Polifix (brand), catheter for puncture of the subclavian vein, surgical drapes - due to their abundance and quality. From the point of view of safe health care, biological tests stand out for checking the sterilization process of greenhouses and autoclaves.

\section{Legacy of international ship-hospital cooperation SS HOPE}

Their permanence favored the rapprochement between different peoples and cultures. In the explanations of Potiguares' interviewees, the learning and donation of equipment and materials were as a legacy. In this case, some expressed themselves like this: 
Valid experience for Medicine, Nursing and Dentistry in the state [...] performed surgeries of cleft lip, cleft palate and contractures caused by leprosy, in the counterpart system, with Dr. Chisholm, at Hospital Infantil Varela Santiago and with Dr. Edward Falces, at Colônia São Francisco de Assis Hospital. (Soares, medical teacher)

UFRN, holder of an intellectual elite, was the institution that benefited the most from the HOPE Project through lectures, courses and interaction with more experienced technicians with more advanced knowledge [...] the State Department of Health also favored health education and childhood vaccination projects. (Barros, medical secretary)

The experience of hospital ship HOPE and its exchange boosted UFRN and some local public health services [...] was an awakening for the state and the Northeast, it can be said [...] presented a new mentality of health care, showing the reality of a developed country. (Leite, nurse teacher)

According to the reports, the experience was successful and is directly associated with work between homologous. There were institutional developments with the revision and implementation of new care protocols. They explained that the actions of this international cooperation went beyond the hospital ship's facilities, benefiting UFRN hospitals, as well as professionals from other health institutions and the Health Department itself, thus:

Health professionals from neighboring states came here [...] participation was easy, open and voluntary [...] this exchange was extremely significant for all of us [...] from Alagoas, the coming of Dr. Úlpio Paulo Miranda resulted in the departure of the HOPEProject, to Maceió, the year after passage through Natal. (Soares, medical teacher)

I was housed with a staff from Recife [...] I remember a nun from Bahia [...] on the ship there were nurses from other states of the Northeast, us, from the School of Nurses of Mossoró, and students of the School of Nursing Auxiliaries of Natal. (Pinto, student at School of Nurses of Mossoró)

Given the emphasis on qualification of human resources in health, it should be clarified that the documentary sources corroborate the interviews and ensure the mobilization of professionals and students from Alagoas, Bahia, Ceará, Paraíba, and Pernambuco, mostly.

On the donations, oral sources recall that public health institutions and UFRN benefited from: dental offices, cardiac monitors, Bird Mark 7-type respirators, educational videos, surgical instruments, aprons, surgical fields, scissors, identification bracelets, among other supplies.

\section{Statements about the season of hospital ship SS HOPE}

Their stay in Natal for ten months (February to December/1972) allowed the exchange between health professionals and students, local and surrounding states. The following are some statements based on the particularities of each experience:

At the time of hospital ship HOPE, its professionals had a very large participation at the University [...] teacher training and internships for medical, dental and nursing students [...] obviously new techniques were developed and learned. (Andrade, secretary professor)
There was a lot of integration between Americans and Potiguares [...] allowed a better qualification of health personnel by applying technologies and performing procedures unknown to the health area [...] its coming brought enormous benefits to the state. (Ramos, secretary economist)

The hospital ship's passage was a very good event for the state [...] treated people who could not leave Natal to other centers [...] brought new teachings and favored many changes in the University Hospital. (Costa, nursing technician)

In the peculiarity of nursing, some interviewees said:

A beautiful gesture, the humanitarian action of HOPE [...] opportunity to meet a more qualified nursing [...] it brought new technologies, new knowledge and new practices, but also acquired our knowledge [...] I was not received nor mentored by any nurse [...] I started observing and gradually got involved with service [...] they made no distinction between us, Brazilian, whether she was a teacher at the School of Nursing Auxiliaries, a nurse at the University Hospital, auxiliary or nursing assistant [...] I do not know if they did not understand our different levels or if they did not want to consider it. (Germano, nurse teacher)

Aside from the abundant resources, I didn't see anything different from what we practiced at the University Hospital [...] they didn't show me anything new, a new technique, much less / was introduced to the head of nurses [...] / thought I was going to the hospital ship to make an improvement, [...] I did not know any private action by nurses, such as supervision of care, routines, protocols, scale of employees, sector organization [...] / kept my schedule and did not want any other involvement. (Barbosa de Oliveira, HUOL nurse)

Worked with dynamism, methods and routines, all well determined [...] the fellow nurses, despite the barriers between languages, were attentive and wanted to know our services, our way of working and our skills, including our improvisations (laughs) [...] the scientific part of the female colleagues was very strong, but have always been sure that our nursing is more human. (Barreto, nurse teacher)

Language was a problem [...] in the Operating Room, I participated in many surgeries, sometimes unable to move away to go to the bathroom, drink water or feed [...] there were no moments to discuss sterilization process, care for surgical patients, projects, protocols, exchange of experiences and knowledge [...] I fulfilled, for two months, the determined scale and only [...] undoubtedly, the American colleagues were well prepared and knew that there were nurses in Natal, but disregarded. (Vila Nova, nurse teacher)

The opinions allowed particular views of different professionals, with different insertions in activities in hospital ship SS HOPE. With regard to the Americans, they seem unanimous about the dynamism of activities, the qualification of their professionals, good working conditions, abundance of resources and good relationship between counterparts.

\section{DISCUSSION}

In Brazil, the movement of international health cooperation began in the transition between the $19^{\text {th }}$ and $20^{\text {th }}$ centuries $^{(15)}$, at the time of the epidemics. These are actions carried out between 
nations with different degrees of development and, when established in solidarity and mutual interests, favor technical-scientific exchange in the most diverse areas ${ }^{(16)}$. In health, they approach professionals through the provision of care in different practice scenarios and thus contribute to the development of new skills, intellectual and professional maturation. They are therefore indispensable to social change ${ }^{(17)}$.

In this case, the experience with the HOPE Project is another chapter in the history of health cooperation between Americans and Brazilians. On this occasion, in particular, with the use of a hospital ship for the purpose of promoting humanitarian aid, health education and training of human resources in health in developing countries. In the Brazilian reality, this project was in two analogous moments: Natal (1972)(4) and Maceió (1973) ${ }^{(18)}$.

During its stay in Natal, 38 educational events were located, distributed among courses and lectures, with predominance of medical themes. This arrangement, possibly, caused discontent, even seemed uncareful by UFRN and the HOPE Project itself. It was to be assumed in the reciprocity between its team and Brazilian professionals the agency on topics private to their professions. This finding is the observation that educational actions when well delineated contribute, positively, to the effective exchange of knowledge and to the collective construction of knowledge, as well as favor collaborative work $^{(19)}$.

Nevertheless, experiences of this nature assume relevance by providing its participants with new learning and unique experiences, even if developed in realities and in unequal working conditions. They also make it possible to analyze the use of health innovations, whose purpose is the population's well-being and even if they seem beneficial, should be explored through the contextualized study, because in some cases, they can serve hegemonic technological domination ${ }^{(20)}$. Furthermore, the quality of health care requires public policies that envision the effectiveness of health services, with the improvement of actions to promote, protect and recover the population's health ${ }^{(21)}$.

Referring to nursing actions, the oral sources informed that, first, it was up to the American nurses to guide and demonstrate to, later, monitor the technique execution by the Brazilian counterpart. That said, it is believed that these procedures envisioned to ensure the development of best practices and, therefore, qualification of nursing care in the various practice and teaching scenarios ${ }^{(22)}$. This corroborated the need for nurses to acquire mastery of advanced health techniques as a result of all technological advances that require the improvement of nursing science ${ }^{(23)}$.

These professionals are remembered as kind, caring, hardworking and skilled. However, there are resentments about lack of knowledge or disregard of Americans about the existence of different levels/performance in Brazilian Nursing, as well as the lack of opportunities for discussions about protocols and routines, management/management of personnel, work processes, care plans and even project development. Perhaps Potiguar nurses, some, also, teachers of the School of Nursing Auxiliaries of Na$\mathrm{tal}^{(24)}$, were anxious for the opportunity to see, on the spot, the deliberate and systematic use of nursing processes ${ }^{(25)}$, since the United States is considered the birthplace of nursing theories.

Attention must be given to the complexity of issues pertaining to international health co-operations through the contextualized understanding of its socio-historical determinants ${ }^{(26)}$. It is a fact that these experiences contribute temporarily and therefore alone are not enough to transform health care and meet the need for human resources training in health. Therefore, it is necessary to continuously monitor health services regarding working conditions, material investments and professional training and updating continuously, as well as guarantees of spaces for discussions on remuneration ${ }^{(27)}$.

Finally, it can be seen that the reciprocity of hospital ship SS HOPE's activities favored the exchange of knowledge and knowledge among the participants of this international cooperation through the review and implementation of new care protocols. With regard to nursing, it is believed that coexistence provided American nurses with knowledge of more humanized care, as well as Potiguares with an advanced practice, combined with discipline and science. Skills and knowledge essential to nursing science.

\section{Study limitations}

Developing this research required overcoming obstacles regarding location and conditions of access to documentary sources. Nevertheless, the documentation was revealing and made possible the reconstruction of part of this history, although gaps are recognized in the deepening of issues such as international relations that detailed this cooperation.

\section{Contributions to nursing}

It is expected that its realization can support new studies that contribute to the construction of knowledge of the history of Brazilian health, RN and UFRN. It brought to light the awakening to the international context, being the tip of the iceberg for building knowledge, especially in nursing, when the geographical delimitation dialogues with other spaces of convenience and interests that need to be unveiled for a greater understanding of facts/events that circumscribe the history of Brazilian nursing.

\section{FINAL CONSIDERATIONS}

This study made it possible to analyze and record another significant episode of health cooperation that occurred between Brazilians and Americans, this time held in Natal, capital of $\mathrm{RN}$, as a result of an agreement between UFRN, the State Government and People to People Foundation that had hospital ship SS HOPE for carrying out education and health care actions. The success of these interventions is attributed to the joint participation between professionals of both nationalities in the system that became known as counterparties.

This event materialized at the opportunity to experience a context of health care, diametrically opposed to the local reality, in the face of a scenario abundant in technology, hospital supplies and qualified human resources. Moreover, coexistence was an opportunity to learn another language and culture. Finally, it is relevant to understand that all participating professionals assimilated new knowledge and new skills, thus inferring the success of this international cooperation.

\section{SUPPLEMENTARY MATERIAL}

https://repositorio.ufsc.br/bitstream/handle/123456789/169653/ 338820.pdf?sequence $=1$ \&isAllowed $=y$ 


\section{REFERENCES}

1. HOPE chega a Natal na quarta-feira de cinzas. Diário Oficial do Rio Grande do Norte. 8 de fevereiro de 1972. Ano 77(4).p488: A1.

2. Barnes RW. The hospital ship Hope. Med Arts Sci. 1969;23(3):41-3.

3. Lima Jr MCF, Santos RM, Costa LMC, Mota FRL, Lima AFS. Circunstâncias que trouxeram o Project HOPE ao estado de Alagoas/Brasil. Hist Enferm Rev Eletron [Internet]. 2018 [cited 2021 Jan 29];9(2):108-21. Available from: http://here.abennacional.org.br/here/v9/n2/a2.pdf

4. Carlos DJD, Padilha MICS. Brazilian and North-American nursing in the HOPE Project (1972): approximations and gaps. Rev Bras Enferm. 2018;71(5):2454-60. https://doi.org/10.1590/0034-7167-2017-0195

5. Convênio entre si celebram, a Secretaria de Estado do Planejamento e Coordenação Geral, a Secretaria de Estado da Saúde Pública e a Universidade Federal do Rio Grande do Norte para a criação das condições necessárias ao desenvolvimento do Projeto HOPE. Diário Oficial do Rio Grande do Norte. 9 de Outubro de 1971: Ano 76(1).p2369: A2.

6. Desobstrução do porto vai começar para esperar o HOPE. Tribuna do Norte. 25 de setembro de 1971: Ano XXII(33). A3.

7. Pessoal começa a chegar para tratar sobre o HOPE. Tribuna do Norte. 6 de janeiro de 1972: Ano XXII(227): A1.

8. Adeus ao HOPE. A República. 7 de dezembro de 1972: Ano LXXXIV(912): A1.

9. Ministério da Saúde (BR). Resolução n 466/12, de 12 de dezembro de 2012. Dispõe sobre pesquisa envolvendo seres humanos [Internet]. Brasília: Ministério da Saúde; 2012 [cited 2021 Jun 29]. Available from: http://bvsms.saude.gov.br/bvs/saudelegis/cns/2013/res0466_12_12_2012.html

10. Ministério da Saúde (BR). Resolução n 510, de 7 de abril de 2016. Dispõe sobre as normas aplicáveis a pesquisas em Ciências Humanas e Sociais cujos procedimentos metodológicos envolvam a utilização de dados diretamente obtidos com os participantes ou de informações identificáveis ou que possam acarretar riscos maiores do que os existentes na vida cotidiana [Internet]. Brasília: Ministério da Saúde; 2016 [cited 2021 Jan 29]. Available from: https://bvsms.saude.gov.br/bvs/saudelegis/cns/2016/res0510_07_04_2016.html

11. Meihy JCS, Ribeiro SLS. Guia prático de história oral: para empresas, universidades, comunidades, famílias. São Paulo: Contexto; 2011.198 p.

12. Tong A, Sainsbury P, Craig J. Consolidated criteria for reporting qualitative research (COREQ): a 32-item checklist for interviews and focus groups. Int J Qual Health Care. 2007;19(6):349-57. https://doi.org/10.1093/intqhc/mzm042

13. Padilha MI, Bellaguarda MLR, Nelson S, Maia ARC, Costa R. The use of sources in historical research. Texto Contexto Enferm. 2017;26(4):e2760017. https://doi.org/10.1590/0104-07072017002760017

14. Minayo MCS. O desafio do conhecimento: pesquisa qualitativa em saúde. 14 ed. São Paulo: HUCITEC; 2014. 407 p.

15. Carlos DJD. Epidemics as perspectives to the professionalization of Brazilian nursing. Hist Enferm Rev Eletron [Internet]. 2020 [cited 2021 Jan 29];1 1(1):4-6. Available from: http://here.abennacional.org.br/here/v11/n1/EDITORIAL_en.pdf

16. Santos RF, Cerqueira MR. South-South Cooperation: Brazilian experiences in South America and Africa. Hist Cienc Saude-Manguinhos. 2015;22(1):23-47. https://doi.org/10.1590/S0104-59702015000100003

17. Zanchetta MS, Guruge S, Oliveira RMP, Felipe ICV, Souto RQ. Brazil-Canada: Launching seeds through community consultation on tackling violence against women. Esc Anna Nery. 2020;24(3):e20190278. https://doi.org/10.1590/2177-9465-ean-2019-0278

18. Costa LMC, Santos TCF, Ferreira LO, Almeida Filho AJ, Santos RM, Lázaro Alcântara E. Project HOPE: American nurses in Brazil (1973). Rev Bras Enferm. 2018;71(4):1956-62. https://doi.org/10.1590/0034-7167-2017-0432

19. Bazilio J, Pereira JA, Figueira MCS, Silva EM. Generating meaningful conversation: World Café in strategic interprofessional planning in Continuing Education. Rev Bras Enferm. 2020;73(5):e20190279. https://doi.org/10.1590/0034-7167-2019-0279

20. Costa LS. Contributions from the critical theory of technology to the analysis of innovation in health services. Interface (Botucatu). 2020;24:e190723. https://doi.org/10.1590/interface.190723

21. Lima J, Dallaria S. The global strategy on public health, innovation and intellectual property: establishment of a priority order for research and development needs in Brazil. Saúde Soc. 2020;29(2):e181162. https://doi.org/10.1590/s0104-12902020181162

22. Vieira NA, Petry S, Padilha MI. Best Practices in Historical Studies of Nursing and Health (1999-2017). Rev Bras Enferm. 2019;72(4): 973-8. https://doi.org/10.1590/0034-7167-2018-0538

23. Salles EB, Barreira IA. Formação da Comunidade científica de enfermagem no Brasil. Texto Contexto Enferm. 2010;19(1):137-146. https://doi. org/10.1590/S0104-07072010000100016

24. Carlos DJD, Germano RM. A escola de auxiliares de enfermagem de Natal e o Hospital Universitário Onofre Lopes. Rev Rene[Internet]. 2009 [cited 2021 Jan 29];10(1):72-80. Available from: https://www.redalyc.org/pdf/3240/324027965008.pdf

25. Garcia TR, Nóbrega MML. Simpósio Nacional de Diagnóstico de Enfermagem: building a knowledge field for Nursing. Rev Bras Enferm. 2019;72(3):801-8. https://doi.org/10.1590/0034-7167-2018-0916

26. Castro-Silva CR. Ethics of care and politics: contributions from the legacy of Maria de Lourdes Pintasilgo. Saúde Debate. 2020;43(spe5):26272. https://doi.org/10.1590/0103-11042019s521

27. Veras R. A contemporary and innovative care model for older adults. Rev Bras Geriatr Gerontol. 2020;23(1):e200061. https://doi. org/10.1590/1981-22562020023.200061 